\title{
PARTICIPATION OF TICKS IN THE INFECTIOUS CYCLE OF CANINE VISCERAL LEISHMANIASIS, IN TERESINA, PIAUÍ, BRAZIL
}

\author{
José Henrique Furtado CAMPOS(1) \& Francisco Assis Lima COSTA(2)
}

\begin{abstract}
SUMMARY
In this study, we detected Leishmania spp. infection in R. sanguineus collected from dogs that were naturally infected with $L$. (L.) infantum. We examined $35 \mathrm{dogs}$ of both sexes and unknown ages. The infected dogs were serologically positive by the immunofluorescence antibody test (IFAT), enzyme-linked immunosorbent assay (ELISA), and Quick Test-DPP (Dual Path Platform), as well as parasitological examination of a positive skin biopsy or sternal bone marrow aspiration. Ten negative dogs were included as controls. The ticks that infested these dogs were collected in pools of 10 adult females per animal. The PCR was performed with specific primers for Leishmania spp., which amplified a 720-bp fragment. Of the 35 analyzed samples, a product was observed in eight samples $(8 / 35 ; 22.9 \%)$. We conclude that the presence of parasite DNA suggests that ticks participate in the zoonotic cycle of canine visceral leishmaniasis, in the city of Teresina, Piauí.
\end{abstract}

KEYWORDS: Rhipicephalus sanguineus; Canis familiaris; Leishmania spp.

\section{INTRODUCTION}

Canine visceral leishmaniasis (CVL) is a disease of great zoonotic potential ${ }^{5}$. It is caused by the protozoan $L$. (L.) infantum in the Americas ${ }^{19}$. The major means of transmission of the parasite to humans and other vertebrate hosts is through the bite of infected female sand flies ${ }^{25}$. Currently, Lutzomyia (Lutzomyia) longipalpis is considered the primary transmitter of the species L. (L.) infantum in Brazil. However, Lutzomyia cruzi in the state of Mato Grosso do Sul and Lutzomyia migonei and Lutzomyia firmatoi in Rio de Janeiro are also considered vectors of visceral leishmaniasis (VL) ${ }^{26,29}$.

The high incidence of CVL in Brazil and the occurrence of autochthonous cases in the absence of phlebotomine vectors suggest the possibility that $R$. sanguineus participates in the transmission of infection in dogs. The importance of $R$. sanguineus in the transmission of pathogens to humans and dogs has been substantiated by recent reviews s,10,11,21,22 $^{\text {. }}$

$R$. sanguineus is the most frequent ectoparasite of dogs in Brazil. In a study of dogs in Belo Horizonte and neighboring counties, the rate of infestation by $R$. sanguineus was found to be $37.9 \%$. In Juiz de Fora, the index was found to be $60.6 \%$ in shelter dogs parasitized by this tick species $^{10,16,24}$.

The likely involvement of $R$. sanguineus in the transmission of $L$. (L.) infantum in dogs was demonstrated in the 1930s in France, where the ability of the tick to mechanically transmit the protozoan to rodents was observed ${ }^{4}$. In Brazil, the presence of morphologically similar forms of Leishmania spp. to "Leptomonas" in ticks collected from dogs with visceral leishmaniasis (VL) has been reported ${ }^{23}$. Other studies have found ticks to be naturally infected with $L$. (L.) infantum ${ }^{7,11}$. The presence of $L$. (L.) infantum in the salivary glands of ticks and the presence of Leishmania spp. RNA were recently reported ${ }^{6,11}$.

The possible participation of $R$. sanguineus in the transmission of VL, particularly in areas where autochthonous cases of CVL occur without the presence of Lutzomyia (Lutzomyia) longipalpis, should be the focus of further studies ${ }^{8}$. Similarly, in areas of high endemicity for CVL, where the euthanasia of dogs with VL shows no positive correlation with a decrease in the incidence of the disease ${ }^{14}$ the possible involvement of other likely vectors should be considered ${ }^{29}$. In this context, the objective of this study was to detect Leishmania spp. in R. sanguineus fed directly to dogs that were naturally infected by $L$. $(L$. $)$ infantum to determine the possible participation of the tick in the cycle of visceral leishmaniasis in the endemic area of Teresina, Piauí.

\section{MATERIALS AND METHODS}

This study was conducted with 65 dogs of both sexes and mixed breed that were from a Brazilian endemic area (Teresina, state of Piauí) and were infested with ticks. However, only $35 \mathrm{dogs}$ had a positive parasitological result upon skin biopsy or aspiration of sternal bone marrow and a positive

(1) Pós-Graduando da Universidade Federal do Piauí (UFPI).

(2) Professor Associado da Universidade Federal do Piauí/CCA/DCCV, Campus da Socopo, 64049-550 Teresina, Piauí, Brazil.

Correspondence to: José Henrique Furtado Campos. E-mail: jhfcampos@ gmail.com 
Table 1

Examination performed on 35 dogs naturally infected by L. (L.) infantum and pooled ticks collected from these animals. Teresina, Piauí, 2012

\begin{tabular}{lccccccccc}
\hline & \multicolumn{3}{c}{ Serology } & \multicolumn{3}{c}{ Parasitological } & \multicolumn{2}{c}{ PCR/Ticks } \\
\cline { 2 - 8 } Tests Dogs & $\mathrm{P}$ & $\mathrm{N}$ & $\%$ & $\mathrm{P}$ & $\mathrm{N}$ & $\%$ & $\mathrm{P}$ & $\mathrm{N}$ \\
\hline Infected & 35 & 0 & 100.0 & 35 & 0 & 100.0 & 08 & 27 \\
Uninfected & 0 & 10 & 100.0 & 0 & 10 & 100.0 & 0 & 10 & 100.0 \\
\hline
\end{tabular}

$\mathrm{P}=$ positive $; \mathrm{N}=$ Negative $\mathrm{PCR}=$ Polymerase chain reaction.

serological diagnosis by indirect immunofluorescence techniques (BioManguinhos, Fiocruz), ELISA (Bio-Manguinhos, Fiocruz) and Quick Test-DPP (Dual Path Platform) for the detection of anti-Leishmania antibodies. The serological diagnosis and PCR were performed in the Laboratory of Parasitology of the Center for Health Sciences, Federal University of Piauí. This project was approved by the ethical commission of the Federal University of Piauí as number 007/12.

Collection of ticks: Ten adult female engorged ticks were collected per animal. Ticks were placed in vials with $70 \%$ alcohol and taken to the laboratory. The identification of ticks was performed according to the classification key of ARAGÃO \& FONSECA (1961)².

In the laboratory, ticks were washed with distilled water and dried on paper towels. With the aid of a scalpel blade, the ticks were sectioned at the side for the complete extraction of material ingested during its blood meal. The extracted material was placed in an Eppendorf tube and stored in a freezer at $-70^{\circ} \mathrm{C}$ until the DNA extraction procedure was performed.

PCR: DNA was extracted from samples taken from ticks and the sternal bone marrow of dogs using a commercial kit from Promega (Cat. \# A1120, Wizard Genomic DNA Purification Kit), according to the manufacturer's recommendations. The PCR reaction mixture was prepared at a final volume of $25 \mu \mathrm{L}$ using SuperMix from Invitrogen, which contains $22 \mathrm{mM}$ Tris- $\mathrm{HCl}$ ( $\mathrm{pH} 8.4$ ), $55 \mathrm{mM} \mathrm{KCl}, 1.65 \mathrm{mM} \mathrm{MgCl}_{2}$, $220 \mathrm{mM}$ of each dNTP (deoxynucleotide triphosphate), and $22 \mathrm{U}$ of recombinant Taq DNA polymerase/mL). The primers used were Lin R4 (5 ‘- GGG GTA GTT GGT AAA TAG GG - 3') and Lin 19 (5 'CAG AAC GCC ACC CCT CG - 3'), which were originally developed by ARANSAY et al. $(2000)^{3}$ and are specific to the minicircle region of Leishmania spp. The mixture for the PCR reaction included $22 \mu \mathrm{L}$ of SuperMix, $1 \mu \mathrm{L}$ of each primer, and $1 \mu \mathrm{L}$ of the DNA sample. Amplification was performed in a thermocycler (Eppendorf Mastercycler Gradient) for a total of 35 cycles, with an initial cycle of $94{ }^{\circ} \mathrm{C}$ for five minutes, followed by 34 cycles of 30 seconds at $95{ }^{\circ} \mathrm{C}, 30$ seconds at $58{ }^{\circ} \mathrm{C}$, and one minute at $72{ }^{\circ} \mathrm{C}$, with a final cycle of seven min at $72{ }^{\circ} \mathrm{C}$. The PCR product was run on a $1.5 \%$ agarose gel, stained with ethidium bromide $(1.0 \mu \mathrm{L} / 10$ $\mathrm{mL}$ ), and viewed in a UV transilluminator (Bioagency). DNA extracts from cultures of Leishmania spp. were used as positive controls. As a negative control, we used a mixture of the reactants used in the PCR reaction without the initial template DNA. Comparative data analyses were performed using Fischer's nonparametric statistical test. The level of significance was set at $p<0.05$.

\section{RESULTS}

Of the 65 dogs examined, all were parasitized by ticks, but only
35 naturally infected dogs (G1) used in this study were reactive in all serological tests (IFAT, ELISA, and RT - DPP) and parasitological examinations performed on a skin biopsy and/or a sternal bone marrow smear $^{20}$. The IFAT showed high titers of antibodies to canine IgG in most of the evaluated samples (Tables 1 and 2). Dogs that were uninfected (G2) were all non-reactive in the exams.

Table 2

The results of PCR performed on 35 pooled samples of $R$. sanguineus collected from dogs naturally infected with $L$. (L.) infantum. Teresina, Piauí, 2012

\begin{tabular}{lcccccc}
\hline \multirow{2}{*}{ Clinical status } & \multicolumn{5}{c}{$\mathrm{PCR}$} \\
\cline { 2 - 6 } & $\mathrm{P}$ & $\%$ & $\mathrm{~N}$ & $\%$ & $\mathrm{~T}$ & $\%$ \\
\hline Infected & 08 & 22.9 & 27 & 77.1 & 35 & 100.0 \\
Uninfected & 0 & 0.0 & 10 & 100.0 & 10 & 100.0 \\
\hline
\end{tabular}

In the 35 naturally infected dogs (G1), the most frequent clinical manifestations were increased superficial lymph node size, weight loss, onychogryphosis, skin lesions, conjunctivitis, ulceration of the skin, alopecia, coryza, desquamation of the skin, keratitis, depigmentation of the nose, pale mucous, apathy, hyperkeratosis and edema as found in other study ${ }^{1}$.

Most uninfected dogs (Group 2) showed no clinical signs of CVL, with the exception of four dogs that had only one clinical sign, either alopecia, weight loss, onychogryphosis, or hyperkeratosis.

The PCR results of pooled samples of $R$. sanguineus collected from eight dogs were positive (8/35-22.9\%). In the group of uninfected dogs, no DNA amplification was observed in the collected $R$. sanguineus or bone marrow samples.

\section{DISCUSSION}

In this study, PCR performed on material extracted from pools of ten engorged adult female ticks from each of the dogs that were naturally infected with $L$. (L.) infantum revealed that $22.9 \%$ of the ticks were infected. It is important to note that we used only adult female ticks that were engorged by spending time feeding on the host. COUTINHO et al. (2005) analyzed ticks collected in various life cycle stages from 21 dogs with symptoms of CVL from the endemic area of Minas Gerais and identified DNA from Leishmania spp. in six ticks (15.4\%). Another study of 128 ticks collected from dogs from an endemic area of VL in Italy found DNA from Leishmania spp. in 13 ticks $(10.1 \%)^{28}$. The results of the present study, conducted in the endemic area of Teresina, present a higher percentage 
of ticks infected by $L$. (L.) infantum, which is significant and alongside other epidemiological factors may be related to participation of ticks in the infectious cycle of the disease, as has been previously suggested ${ }^{7,11,15}$. However, amastigote forms of the parasite were not detected in ticks in this study. Nonetheless, transmission has been demonstrated experimentally, and flagellated forms, such as the infective form of the parasite, have been observed in material extracted from ticks ${ }^{7,23,27}$.

The involvement of ticks in the epidemiology of CVL requires further study. However, many studies have detected DNA and RNA from Leishmania spp. in ticks, with an infection rate that is higher than the natural rate of infection in Lutzomyia longipalpis ${ }^{7,11,18}$. Notably, RNA from Leishmania spp. has been detected in $R$. sanguineus maintained after blood feeding in a greenhouse under appropriate temperature and humidity conditions for ten days. Additional factors support the participation of the tick in the life cycle of CVL, including its extremely common contact with dogs, its longevity, its ability to adapt to the environment, the process and durability of blood feeding and the locomotion capacity of males seeking a new host ${ }^{6,9,10,28}$.

In addition to these considerations, one very important fact is that DNA found in adult females has also been detected under experimental conditions in eggs and in the subsequent life stages of the tick ${ }^{13}$. When feeding on the host, $R$. sanguineus excretes a substantial amount of potentially contaminated saliva. A study reported the presence of $L$. (L.) infantum DNA in the salivary glands of ticks ${ }^{11}$

Although it has not been proven that ticks can transmit infections to dogs, dogs can transmit infections to ticks. One study demonstrated this by placing healthy ticks maintained in a laboratory on dogs with VL. After a few days, Leishmania spp. DNA was detected in the respective ticks, and this infection was present in subsequent stages of tick development ${ }^{23}$.

In the slides examined in our study, which were created with material extracted from ticks, no evolutionary form of Leishmania spp. or any similarly flagellated forms were observed. However, specimens of $R$. sanguineus infected with shapes similar to promastigotes of $L$. (L.) infantum have been reported, but this result should be viewed with some caution because some monogenetic trypanosomatids found in $R$. sanguineus can be easily confused with promastigotes of Leishmania spp. ${ }^{17,23,27}$.

The possibility of transmission of $L$. ( $L$.) infantum by $R$. sanguineus implies that new measures are necessary for the control of VL due to the difficulty of controlling this ectoparasite, which is widespread in Brazil ${ }^{10}$. New experimental studies for adapting a proper method of xenodiagnostic testing using ticks and demonstrating the transmission of infection from an infected tick to a dog will be needed to definitively prove the role of $R$. sanguineus in the transmission of $L$. (L.) infantum to dogs.

Based on the results presented herein, we conclude that the presence of Leishmania spp. in ticks collected from parasitologically positive dogs from areas in which CVL is endemic demonstrates that this arthropod is infected and may have epidemiological importance, particularly given the large number of positive dogs and the low incidence of natural infection in sandflies (less than $1.0 \%)^{18}$. This possibility should be corroborated with various autochthonous VL cases in which the presence of Lutzomyia longipalpis is not detected.

\section{RESUMO}

\section{Participação do Rhipicephalus sanguineus no ciclo infeccioso da leishmaniose visceral canina em Teresina, Piauí, Brasil}

Neste estudo foi detectada infecção por Leishmania spp. em Rhipicephalus sanguineus ( $R$. sanguineus) de cães naturalmente infectados por Leishmania (Leishmania) infantum $=$ L. (L.) infantum. Foram utilizados 35 cães de ambos os sexos e idades desconhecidas, sorologicamente positivos pelas técnicas de reação de imunofluorescência indireta (RIFI), enzyme-linked immunosorbent assay (ELISA) e Quick Test-DPP (Dual Path Plataform), e com exame parasitológico positivo em biópsia de pele ou punção de medula óssea esternal e 10 cães domiciliados negativos, como controle. Os carrapatos que infestavam esses cães foram coletados em pool de 10 fêmeas adultas por animal. A Reação em Cadeia pela Polimerase $(\mathrm{PCR}=$ Polymerase Chain Reaction) foi realizada com primers para Leishmania spp., que amplificaram $720 \mathrm{pb}$. O resultado das 35 amostras processadas revelou a amplificação de oito amostras (8/35 - 22,9\%). Conclui-se que a presença do DNA do parasita sugere que carrapatos podem estar participando do ciclo zoonótico da leishmaniose visceral canina na cidade de Teresina, Piauí.

\section{REFERENCES}

1. Almeida MAO, Jesus EEV, Sousa-Atta MLB, Alves LC, Berne MEA, Atta AM Clinical and serological aspects of visceral leishmaniasis in Northeast Brazilian dogs naturally infected with Leishmania chagasi. Vet Parasitol. 2005;127:227-32.

2. Aragão HB, Fonseca F. Notas de ixodologia. VIII. Lista e chave para os representantes da fauna ixodológica brasileira. Mem Inst Oswaldo Cruz. 1961;59:115-29.

3. Aransay AM, Scoulica E, Tselentis Y. Detection and identification of Leishmania DNA with naturally infected sand flies by seminested PCR on minicircle kinetoplastic DNA. Appl Environ Microbiol. 2000;66:1933-8.

4. Blanc G, Caminopetros J. La transmission du Kala-azar méditerranéen par une tique: Rhipicephalus sanguineus. C R Acad Sci. 1930;191:1162-4.

5. Camargo JB, Troncarelli MZ, Ribeiro MG, Langoni H. Leishmaniose visceral canina: aspectos de saúde pública e controle. Clín Vet. 2007;71:86-92.

6. Colombo FA, Odorizzi RMFN, Laurenti MD, Galati EAB, Canavez F, PereiraChioccola VL. Detection of Leishmania (Leishmania) infantum RNA in fleas and ticks collected from naturally infected dogs. Parasitol Res. 2011;109:267-74.

7. Coutinho MTZ, Bueno LL, Sterzik A, Fujiwara RT, Botelho JR, De Maria M, et al. Participation of Rhipicephalus sanguineus (Acari: Ixodidae) in the epidemiology of canine visceral leishmaniasis. Vet Parasitol. 2005;128:149-55.

8. Dantas-Torres F, Brandão-Filho SP. Visceral leishmaniasis in Brazil: revisiting paradigms of epidemiology and control. Rev Inst Med Trop Sao Paulo. 2006;48:151-6.

9. Dantas-Torres F. Canine vector-borne diseases in Brazil. Parasit Vectors. 2008a;1:25.

10. Dantas-Torres F. The brown dog tick, Rhipicephalus sanguineus (Latreille, 1806) (Acari: Ixodidae): from taxonomy to control. Vet Parasitol. 2008b;152:173-85.

11. Dantas-Torres F, Lorusso V, Testini G, de Paiva-Cavalcanti M, Figueredo LA, Stanneck $\mathrm{D}$, et al. Detection of Leishmania infantum in Rhipicephalus sanguineus ticks from Brazil and Italy. Parasitol Res. 2010a;106:857-60.

12. Dantas-Torres F, Martins TF, de Paiva-Cavalcanti M, Figueredo LA, Lima BS Brandão-Filho SP. Transovarial passage of Leishmania infantum kDNA in artificially infected Rhipicephalus sanguineus. Exp Parasitol. 2010b;125:184-5. 
13. Dantas-Torres F, Latrofa MS, Otranto D. Quantification of Leishmania infantum DNA in females, eggs and larvae of Rhipicephalus sanguineus. Parasit Vectors. 2011;4:56.

14. Dietze R, Barros GB, Teixeira L, Harris J, Michelson K, Falqueto A, et al. Effect of eliminating seropositive canines on the transmission of visceral leishmaniasis in Brazil. Clin Infect Dis. 1997;25:1240-2.

15. Gezoon. Gerência de Zoonoses. Teresina: Fundação Municipal de Saúde; 2009. Available from: http://saude.teresina.pi.gov.br/zoonoses

16. Linardi PM, Nagem, RL. Pulicídeos e outros ectoparasitos de cães de Belo Horizonte e municípios vizinhos. Rev Bras Biol. 1973;33:529-38.

17. Machattie C, Chadwick CR. Notes on a trypanosome infection of the dog tick Rhipicephalus sanguineus in Iraq. Trans R Soc Trop Med Hyg. 1930;23:417-20.

18. Martín-Sánchez J, Gállego M, Barón S, Castillejo S, Morillas-Marquez F. Pool screen PCR for estimating the prevalence of Leishmania infantum infection in sandflies (Diptera: Nematocera, Phlebotomidae). Trans R Soc Trop Med Hyg. 2006;100:527-32.

19. Mauricio IL, Howard MK, Stothard JR, Miles MA. Genomic diversity in the Leishmania donovani complex. Parasitology. 1999;119:237-46.

20. Meinkoth JH, Cowell RL, Tyler RD, Morton RJ. Coleta e preparo de amostras. In: Cowell RL, Tyler RD, Meinkoth JH, DeNicola DB, editores. Diagnóstico citológico e hematologia de cães e gatos. São Paulo: Medvet; 2009. p. 1-8.

21. Otranto D, Dantas-Torres F, Breitschwerdt EB. Managing canine vector-borne diseases of zoonotic concern: part one. Trends Parasitol. 2009a;25:157-63.

22. Otranto D, Dantas-Torres F, Breitschwerdt EB. Managing canine vector-borne diseases of zoonotic concern: part two. Trends Parasitol. 2009b;25:228-35.
23. Paz GF, Ribeiro MFB, Michalsky EM, da Rocha Lima AC, França-Silva JC, Barata RA, et al. Evaluation of the vectorial capacity of Rhipicephalus sanguineus (Acari: Ixodidae) in the transmission of canine visceral leishmaniasis. Parasitol Res. 2010;106:523-8

24. Rodrigues AFSF, Daemon E, D’Agosto M. Investigação sobre alguns ectoparasitos em cães de rua no município de Juiz de Fora, Minas Gerais. Rev Bras Parasitol Vet. 2001;10:13-9.

25. Santa Rosa ICA, Oliveira ICS. Leishmaniose visceral: breve revisão sobre uma zoonoze reemergente. Clín Vet. 1997;2:24-8.

26. Santos SO, Arias J, Ribeiro AA, de Paiva Hoffmann M, de Freitas RA, Malacco MA Incrimination of Lutzomyia cruzi as a vector of American visceral leishmaniasis. Med Vet Entomol. 1998;12:315-7.

27. Sherlock I. Notas sobre a transmissão da leishmaniose visceral no Brasil. Rev Bras Malariol D Trop. 1964;16:19-26.

28. Solano-Gallego L, Rossi L, Scroccaro AM, Montarsi F, Caldin M, Furlanello T, et al. Detection of Leishmania infantum DNA mainly in Rhipicephalus sanguineus male ticks removed from dogs living in endemic areas of canine leishmaniosis. Parasit Vectors. 2012;5:98

29. Souza MB, Marzochi MCA, Carvalho RW, Ribeiro PC, Pontes CS, Caetano JM, et al Ausência da Lutzomyia longipalpis em algumas áreas de ocorrência de leishmaniose visceral no município do Rio de Janeiro. Cad Saúde Pública. 2003;19:1881-5.

Received: 3 January 2013

Accepted: 27 January 2014 